\title{
Fostering Engagement: The Role of International Education in the Development of Global Civil Society
}

\author{
JAMES M. SKELLY \\ Coordinator for Peace \& Justice Programming, bCa; Visiting Professor of Peace Studies, \\ Magee College, University of Ulster
}

\section{Resumen}

Este artículo trata de describir los problemas fundamentales que atañen a la educación internacional y al estudio en el extranjero, unas preocupaciones que requieren de nuestros esfuerzos. Es además un intento por abordar aquello que necesitamos para la búsqueda de compromisos con los monumentales problemas que acechan a la humanidad. Este artículo sugiriere, además, que los educadores internacionales deben implantar su trabajo en un amplio y convincente discurso que pueda aportar una visión que no esté exclusivamente centrada en el estado y/o el mercado, sino que contrariamente sea global y principalmente humano en su orientación. Debería ser un requisito en las instituciones de educación superior que todos los estudiantes desarrollen un periodo significativo de su formación en el extranjero, con el propósito de ayudarles a ver el globo como un contexto, y un referente fundamental, de sus vidas. Esta debería ser la primera tarea de los programas de estudio en el extranjero.

Palabras clave: educación, programas de estudios en el extranjero, ciudadanía global, sociedad civil global.

\begin{abstract}
This essay is an effort to describe the foundational problems in international education and study abroad that constrain our efforts, as well as an attempt to sketch out what we need to do to foster engagement with the monumental problems that humanity faces. In addition, the essay also endeavours to suggest that international educators embed their work in a broad and compelling discourse that might provide a vision that is not exclusively focused on the state and/or the market, but is instead global and human centric in its orientation. It should be a requirement at higher education institutions that all students engage in a significant period of study abroad in order to help them see the globe as the context, and fundamental referent, for their lives. This should be the primary task of study abroad programs.
\end{abstract}

Key words: education, study abroad programs, global citizenship, global civil society. 
The future, as we know, looks increasingly problematic. Soil has been rapidly eroding on the agriculturally productive land on the planet, water is becoming an ever more scarce resource, and biodiversity is in such serious decline that there is an unprecedented mass extinction of species underway (Harper, 2008: 47-57). In tropical forests where 50\% of all land species live, estimates suggest that between $4-6,000$ species have been disappearing every year (Harper, 2008: 57). India once produced 30,000 separate varieties of rice, but today most rice production is centered on 10 species. In other words, "the world's available gene pool" has shrunk inexorably! (Harper, 2008: 62). And this is to say nothing of climate change, pervasive hunger among many of the world's peoples, nor the unsustainable dependence of almost all societies on fossil fuels. James Lovelock, who articulated the Gaia thesis that the earth is a living organism, estimates that by the end of this century there will be nearly 5 billion less people on the planet than there are currently (Aitkenhead, 2008).

In his book Our Final Hour?, Martin Rees (2003), the noted Cambridge scientist, takes an even more grim perspective and estimates that humans have only a 50/50 chance of surviving the current century unless we radically change our approach to our existence on the planet. The question for international educators is, "are we doing enough to truly meet the challenges of living on this planet that we are sure to face in the coming decades?", as Rees wonders, or are we blithely proceeding with our professional and personal routines, even though our intuition tells us that the students we are purportedly engaged in educating will face the most profound challenges humanity has ever confronted.

The mission statements of study abroad providers, as well as colleges and universities in the us and elsewhere, increasingly make a nod to these challenges by often suggesting that they want to educate students to become "sensitive participants in the larger world", or that they are helping to foster "international citizenship", or to create so-called "global citizens". There seems however to be a lack of connection between the words in mission statements and the kind of education students are receiving concretely. We know what the challenges are, and that they are global in nature: climate change; poverty; environmental degradation; militarism; and, increasing hunger, among myriad others - thirty-seven countries were hit by food riots in the first five months of 2008, including Cameroon, Niger, Egypt and Haiti. Unfortunately, despite the fine sounding words, very few international education programs fundamentally address the problems our students, and humanity more broadly, will face in the decades to come. 
Many supporters of study abroad in the United States have felt, however vaguely, that any experience abroad for American students would contribute to the general global need for educated citizens and help to foster greater understanding between peoples of different cultures. In this way, study abroad might make a modest contribution to creating a more peaceful and coherent global order. Perhaps this is correct, but the challenges we face are of such magnitude that we must bring much greater intentionality to our programs in the United States and abroad.

This lack of intentionality has been compounded by the fact that many international educators, and the institutions that support them such as Nafsa, have often articulated a truncated view of their work. Thus, international education is often characterized as contributing to "global economic competitiveness", the national security of the United States, or preparing students for a global labor market. From a limited national context there may be nothing wrong with such sentiments, but many of those who work in the field sense that these foci are morally, politically and intellectually inadequate in facing the global challenges of the future. One reason for this may be that international educators have yet to embed their sentiments in a discourse with solid theoretical foundations that provides an alternative vision that is more in accord with both their own sentiments and the nature of the challenges the people of the planet face.

This essay is an effort to describe the foundational problems in international education and study abroad that constrain our efforts, as well as an attempt to sketch out what we need to do to foster engagement with the monumental problems that humanity faces. In addition, the essay also endeavours to suggest that international educators embed their work in a broad and compelling discourse that might provide a vision that is not exclusively focused on the state and/or the market, but is instead global and human centric in its orientation. It should be a requirement at higher education institutions that all students engage in a significant period of study abroad in order to help them see the globe as the context, and fundamental referent, for their lives. This should be the primary task of study abroad programs.

\section{Foundational Problems}

Although the discourse of international education has begun to shift modestly in recent years to one focused on peace, justice, and public diplomacy through the efforts of individuals like recent Nafsa Presidents, 
Ron Moffatt and Everett Egginton, the perspective that has been predominant in the United States has tended to distort the inherently global perspective that international education should naturally foster throughout the world. Study abroad, and the hosting of international students, has been seen through the lens of national interest and as such, tends to put the United States, and its individual citizens, first. The distorting effects of such a state-centric perspective have also been clearly evident in other areas such as environmental policy, foreign affairs, and the use of unilateral military force, but the tragedy is that international education should by its very nature transcend such parochialism. The literary critic and public intellectual, Edward Said, argued that we can only overcome this parochialism "by acknowledging that the map of the world has no divinely or dogmatically sanctioned spaces, essences, or privileges" (Said, 1993: 199).

But the problem is deeply rooted and pervasive. As one of the characters in the Irish playwright Brian Friel's (1981: 43) play Translations opines regarding an imperial power that Ireland suffered for too many years, "It can happen that a civilization can be imprisoned in a linguistic contour which no longer matches the landscape of fact". To the extent that study abroad providers focus primarily on issues like "cross-cultural understanding", rather than the deeper structural conditions that create linguistic contours that confine our work, their programs militate against the development of a more generalized sense of "global citizenship" focused on the concrete problems of humanity. Paulo Freire (1985: 113), the Brazilian educator, has argued instead that we must transcend illusions about a "humanistic education for mankind without the necessary transformation of an oppressed and unjust world". "Such a dream", Freire says, "actually serves the interests of the advantaged..." - in other words, most of "us".

The cultural roots of these problems reside not only in the well documented exceptionalism that has defined us political and cultural life, but also in the socialization of a vast number of individual Americans. The sense of being special and feeling entitled is tied to what Christopher Lasch thirty years ago labelled "the culture of narcissism" (Lasch, 1979 and 1984: 184) makes the point that it is not Narcissus self-love that is problematic, but rather that "he fails to recognize his own reflection" and thus, "lacks any conception of the difference between himself and his surroundings".

This sensibility certainly manifests in the realm of international education, and the consequence is that in spite of our best efforts, many of our students come to think that the world is somehow really about 
them. A 1995 report by the American Council on Education noted that the fundamental problem in expanding international education was that American "domestic culture is insular, provincial, and parochial" and that too "many Americans, including undergraduates cling to their own Splendid Isolation" (American Council on Education, 1995: 3). The problem is also captured by the question University of Chicago philosopher Martha Nussbaum asks in her book, Cultivating Humanity (1997), "Why should one care about India, if one defines oneself as above all an American?". She answers by arguing that education for world citizenship requires transcending the inclination of both students and educators to define themselves primarily in terms of local group loyalties and identities" (Nussbaum, 1997: 67).

In addition, and tied to the cultural sensibility discussed above, is the increasingly market-centric perspective that informs international education. This is manifest in the problem of commodification that international education, and education more broadly, faces. Chris Whittle's Channel One, for example, makes the process explicit and sells the attention of students to advertisers by embedding advertisements in "free" news programs and related equipment distributed to schools. Although such practices are well advanced in the United States, seeing higher education as a commodity, and students as consumers, is also becoming predominant in many parts of the world as is evident in the exhibits that tend to dominate the conventions of Nafsa and other educational organizations.

Education as a "service" for which one pays is being resisted by a wide variety of actors in spite of, and because of, its inclusion in the General Agreement on Trade in Services (GATS). Although UnESCO (2004: 9) has suggested that "The inclusion of trade in higher education services within the framework of GATS is a reality and will not change", the commodification of higher education is being challenged by the European Students' Union, the International Association of Universities, education unions, and various higher education institutions. The Association of Universities and Colleges of Canada, the American Council on Education, the European University Association, and the Council for Higher Education Accreditation issued a Joint Declaration a few years ago in which the first principle states that "Higher education exists to serve the public interest and is not a commodity" (quoted in UNESCO, 2001: 10). Similarly, the European Students' Union challenged the inclusion of higher education in GATS and rejected "the notion of students as consumers", and instead stated that students "should be seen as partners 
by the Higher Education Institutions (HEIs) rather than paying customers" (quoted in UNEsCO, 2001: 11).

Commodification in study abroad is however well advanced, and most providers, as reflected in their marketing, see students as narcissistic consumers. Mike Woolf (2006: 140), of the Foundation for International Education, for example, has argued forcefully that, "The call for programme growth in non-traditional locations is not based on solid academic grounds but on a shallow pursuit of the new". Woolf goes on to suggest that many such marketing efforts use the language of tourism advertisements designed to get the attention of self-centered student consumers - for example, "When you tire of techno, have a quiet drink with Taoist monks", as it says in one advertisement he quotes (Woolf, 2006: 137). As the psychoanalyst, Joel Kovel (1981: 106) has noted, the character of contemporary narcissism can be understood as "a neurosis of consumption". The consequence in study abroad marketing according to Woolf, is that "there is rarely a sense of serious exploration beyond the self" (Kovel 2006: 137) and thus, the problem of thinking that the world is really about oneself remains. As the Stoic philosopher Seneca, quoting Socrates, remarked, "Why do you wonder that globe-trotting does not help you, seeing that you always take yourself with you?"

\section{Global Citizenship?}

The seemingly progressive response to such commodification has been to offer an expanded idea of citizenship, but such notions tend to be rife with confusion. Martha Nussbaum emphasizes "World citizenship", and many other organizations speak of "global citizenship". Even Woolf's foundation reverts to the very kind of advertising that he criticizes when it says that it tries to prepare students for "international citizenship". All of these terms are problematic if seen through the lens of traditional state informed citizenship. However, state centric notions of citizenship are in decline because of the deep structural crises that have developed in our politics due to globalization and the end of a single dominant conception of history.

Francis Fukuyama (1993) was correct when he suggested that we were at "the end of history" because he assumed a single conception of history had triumphed. What Fukuyama failed to see however was that we were at the commencement of a plurality of histories that have engendered a plurality of narratives and spaces. It is within these narratives and spaces, as 
Paul Barry Clarke argues in Deep Citizenship (1996: 5-6), that we are able to imagine an enhanced politics in which citizenship is revived "while avoiding an extension of the boundaries of the state". The multitude of histories, and the multitude of voices such histories empower, does not therefore look nostalgically at the political citizen of the past, but opens up possibilities for a politics and citizenship of the future. Such a citizenship does not deny being a citizen of a state, but radically expands our conception of citizenship to attend to those concerns which states are no longer capable of addressing - in other words, a global citizenship that addresses the global political order and the challenges we face within that order.

The shallowness of traditional notions of citizenship, as well as the fragmentation of societies and the multiple perspectives that have come to the fore, have generated "the possibility of new political spaces and the development of political as well as civil society" at a global level (Clarke, 1996: 105). Rather than individuals centered by the master narratives of the past, the consequences of increasing numbers of de-centered individuals may actually provide the capacity "to critically take the perspectives of others and engage in an enlargement of the mind" (Clarke, 1996: 107). Such a capacity is an absolute necessity in order to be able to act towards the universal and without which it is impossible to reach beyond selfishness, sectionalism, and sectarianism" (Clarke, 1996: 107) - in the context of this essay, to become "global citizens" therefore, within a global civil society.

\section{Global Civil Society}

Although it has enjoyed much wider currency in academic and intellectual circles in Europe and other parts of the world, the theoretical developments surrounding the idea of "global civil society" may provide the conceptual foundations to further support the development and status of work in international education, as well as providing a discourse that embodies the sometimes inchoate vision that most international educators hold. Global Civil Society 2002 (Glasius, et al, 2002), the yearbook produced annually by researchers associated with the Centre for the Study of Global Governance at the London School of Economics, mapped the global flows of students studying abroad and argued that, "A growing practice of studying abroad may therefore be one catalyst of the emergence and spread of global civil society" because "students are major transmitters of knowledge and ideas, and interlocutors across cultures" (Glasius, et al. 2002: 264). 
The idea of "civil society" has a long and distinguished history and can be traced back to Cicero and Aristotle and in recent centuries from Adam Ferguson, through Locke, Adam Smith, Hegel, and most notably from the perspective of this essay, Jeremy Bentham. In the Greek and Roman conception, which was dominant in European political thought until 1800 or so, civil society was co-terminus with the state. In the early 19 th century however, civil society and the state begin to be seen as separate entities, especially in the work of Bentham, who saw them as oppositional.

Although its meaning has changed over the years, the idea of "civil society" was utilized in contemporary times by activists challenging the state in the countries of Central and Eastern Europe under communist rule. It was this distinction between civil society and the state that was seized upon by dissidents who suffered the lack of freedom in the former regimes east of the Iron Curtain. Perhaps the most significant in this regard were Adam Michnik in Poland, György Konrad in Hungary, and Vaclav Havel in the then Czechoslovakia. Michnik's The New Evolutionism (1987), Konrad's Antipolitics (1984), and Havel's Living in Truth (1990), among other works, became required reading for political dissidents in the Communist countries. In their writings they focused on the right to the free association of people - a civil society, in other words rather than a state-centric one within the Communist states. The shorthand for this was the idea that "civil society" was in opposition to the pervasive attempts of the state to organize, and therefore control and legitimate, all forms of associational activity on the part of individuals in society. As Mary Kaldor has noted, "the emphasis was on self-organization and civic autonomy in reaction to the vast increase in the reach of the modern state" (Kaldor, 2003: 21).

When I went to Hungary for the first time in the summer of 1986, what I encountered then and in subsequent visits during the next several years was the blossoming of associational activity uncontrolled by the state. Those involved understood it as the flowering of "civil society" - and the historic discourse of civil society provided the dissidents involved with a meaningful narrative about their activities, as well as a sense that they were on the "right side of history". To me, the exemplar of this flowering was the organization founded by students - the League of Young Democrats, or FIDESz, as it was known in Hungary. Under communism, the only legitimate organization for young people interested in a political or governmental career was the Young Communist League, which was approved by the government and the Communist Party. In contrast, FIDESz was a group of freely associating young people who understood themselves as one of the manifestations of a long suppressed civil society. 
Kaldor discusses this particular epoch in Central and Eastern Europe in a chapter from Global Civil Society (Kaldor, 2003). In it, she notes how what she calls "The Ideas of 1989" which led to the collapse of the communist states of the Soviet bloc, provided the foundation for the emergence of discussions about a "global civil society" (Kaldor, 2003: 50-73). Michael Edwards, director of the Ford Foundation's program on governance and civil society, discusses in more abstract form how those events and perspectives provided the soil within which the global civil society discussions of the 1990's became rooted. He also demonstrates how the larger structural transformations in the global economy during this period created a greater sense of insecurity in many of the worlds' peoples - thus, what are called "precarity movements", because of the precariousness of contemporary life in ever increasing parts of the world. In other words, as Edwards' asserts, such responses may mean that a global civil society is a manifestation of "people power writ large" (Edwards, 2004: 15).

In sketching out the basics of three contrasting schools of thought regarding civil society, Edwards suggests that Americans may well resonate most with what he calls the "neo-Tocquevillian" perspective which focuses on the idea of creating the "good society" (Edwards, 2004: 8). While dissidents in Central and Eastern Europe were deploying the discourse of civil society as free associational life to challenge the state, a parallel discourse was developing in the United States that focused on the "good society" in which justice and social equality were valorized. This discourse implicitly challenged the tendencies of large corporations as well as the state, and had its roots in Alexis de Tocqueville's insights into the vitality of American social and political life during his tour of the us in the 1830's. What Tocqueville noted then were the "habits of the heart" of the Americans that derived from the dominant political discourse that they were historically embedded in - republicanism, and its emphasis on civic virtue both on the part of individual citizens and the Republic itself. These so-called "habits of the heart" were the norms that implicitly contributed to the vitality of American civil society by legitimating a broad spectrum of civically virtuous associational activity on the part of citizens, as Robert Bellah and his colleagues have noted in a book by that name (Bellah, et al., 2007).

The sequel by Bellah et al., The Good Society (1992), was more proscriptive and argued for the recovery of the civil society tradition in the us which many scholars suggested was under increasing threat. Most notable in this regard was Robert Putnam's Bowling Alone (Putnam, 2001), first published a little over ten years ago, which suggested that Americans 
were increasingly atomized and isolated. Recent polls have suggested that lack of social engagement has increased even more in the us since Putnam published Bowling Alone, and thus the debate that has developed is about "the value of voluntary associations in curbing the power of centralizing institutions, protecting pluralism, and nurturing constructive social norms especially generalized trust and cooperation" (quoted in Edwards, 2004: 7).

Edwards however, argues that there is a third definition of civil society as the "public sphere" which "is the basis for the current and widespread revival of interest in direct, deliberative, or participatory democracy" and which, he argues, is "an essential complement to the representative components of political systems[...]" This kind of "dialogic politics", he argues, may be the only route "to reach a normative consensus around a plurality of interests and positions [...]" (Edwards, 2004: 59). However, Edwards makes the important point that the three perspectives on civil society "are not mutually exclusive, since the goals of the good society are most likely to be achieved when an enabling environment for all associational life is combined with support for specific associational forms" (Edwards, 2004: 86). This "civil society ecosystem", as Edwards calls it, has however one essential component. These are the associations that combine action at both the individual and structural level since they build the dispositions "to care for the common good and to address the barriers that stand in its way" (Edwards 2004: 87). The contemporary German social philosopher, Jürgen Habermas, articulated similar sentiments when he described the character of contemporary civil society as "composed of those more or less spontaneously emergent associations, organizations, and movements that, attuned to how societal problems resonate in private life spheres, distil and transmit such reactions to the public sphere" (quoted in Kaldor, 2003: 21). And like Edwards, Habermas emphasizes that, "The core of civil society comprises a network of associations that institutionalizes problem solving discourses of general interest inside the framework of organized public spheres" (quoted in Kaldor, 2003: 21).

Although the term "global civil society" came to be used in the early 1990's as a counter to what many saw as the increasing power of global corporations, as well as the contemporary state, Edwards argues that the creation of a viable global civil society requires a synthesis of associational life, the good society, and the public sphere. At the global level therefore, states "will remain the duty bearers of international treaties", transnational networks will be "essential to enforce public compliance", and a global public sphere will be "required to foster debates about international norms" (Edwards 2004: 91-92). 
This, of course, is where international education can be truly significant. Broadly speaking, our efforts are focused on helping individuals to transcend narrow national cultures and identities through the free association of students within a global context. At the same time we can go several steps further by providing a critical perspective on the imperatives of global corporations and the institutions of states by helping to create a global public sphere where students and faculty, acting as global citizens, can foster much needed debates about international norms on a variety of issues. Unfortunately, this broad context has for the most part not been attended to by international educators, and instead for lack of an alternative vision, the field has tended to focus on the more limited concerns of states and corporations. It is now necessary to begin to broaden that discussion and to lay some modest intellectual foundation for the further development of our understanding of the importance of international education to creation of citizenship within the new global civil society.

\section{What Is to Be Done?}

There are several levels at which our efforts should be focused in order to concretely achieve such a vision. In general, international educators can help to overcome the distortions that inform parochial educational perspectives by making the principal focus of their efforts be the globe and its people. Without question, we must also work to revive civil society in the United States by challenging those who would try to further centralize power through the institutions of the state or through corporate structures. This means that wherever we are engaged, we should help our American colleagues to recover those habits of their hearts that are republican, rather than imperial, in nature. Reviving that individual and collective sense of civic virtue, and the modesty inherent in it, would help to strike a chord with many in the United States and abroad who know, to paraphrase Said (1993: 377), that the map of the world does not include any divinely sanctioned spaces and privileges.

As a corollary to the above, we should also move beyond any direct concern with international education as contributing to the national security of the United States. Although the work of international education may in fact contribute to security in the United States, we should follow the lead of the United Nations and think of how our work might contribute to "human security", Human security is informed by the "dual notions of protection and empowerment of people" (UN Commission on Human 
Security, 2003: 121), and the sense that "knowledge, education and democratic engagement are inseparable - and essential" in this task, according to the report issued by the un Commission on Human Security (2003: 120). As educators, we must therefore aim to "raise awareness of the social environment and provide the tools to address problems" by teaching "students to reason, to consider ethical claims, and to understand and work with such fundamental ideas as human rights, human diversity and interdependence" and therefore "instil in the content" of our educational efforts "a new emphasis on ethical values - and on public debate and democracy" (un Commission on Human Security, 2003: 121).

Our most difficult challenge is resisting the consumerist sensibilities that have begun to pervade education both at home and abroad. If we are really to foster global civil society and citizenship, we must not only get students, and their teachers, out of their societies of origin for a significant part of their education, but we also must work to get consumer culture out of students and their teachers. In other words, faculty and higher education administrators should be working against the "relentless commodification" (Said, 1993: 387) of education in order to help students understand the manner in which the consumerist sensibilities to which they have been socialized distorts their understanding of other cultures and peoples, as well as the global problems we face as humans upon the planet.

At a very basic level, students choose to study because they want new understandings and new experiences - this is especially true for students who choose to study in a society and culture other than the one where they underwent primary socialization. However, they face two fundamental challenges: one is that their base realities are often those of television and popular cinema rather than more visceral experiences. Thus, I will often hear American students studying in Ireland who, when they come upon an old estate, exclaim, "That's just like in Harry Potter", or something similar. Secondly, their experiences in a new society, and thus their consequent understanding of life's nuances, are increasingly packaged for them even in the realm of study abroad. They may have hoped to encounter the serendipitous while abroad and have experiences unmediated by various interested institutions, but this too is increasingly denied them as international education organizations engage in ever more elaborate projects to assess what students have learned, and thus refine the packaging of student experience. One consequence, as Walter Benjamin (1992: 83) has noted, is that "experience has fallen in value" and thus people are unable to tell stories in which the wisdom of personal experience is embedded. 
In his essay, The Message in the Bottle, the novelist Walker Percy (1989), captured the desire of people to have bona fide experiences, however seemingly perverse. He posed a series of rhetorical questions at the very beginning of the essay such as, "Why do people often feel so bad in good environments and good in bad environments?", for example. Or, "Why is it harder to study a dogfish on a dissecting board in a zoological laboratory in college where one has proper instruments and a proper light than it would be if one were marooned on an island and, having come upon a dogfish on the beach and having no better instrument than a pocket knife or hair pin, one began to explore the dogfish?". And, "Why was it that when Franz Kafka would read aloud to his friends about the sadness and alienation of life in the twentieth century everyone would laugh until tears came?" (Percy, 1989: 4-5). Percy goes on to suggest that the answer to these questions is to be found by understanding the manner in which our language, deeply embedded and previously organized into culturally defined packages of knowledge, destroys and constrains our experience of life (Percy, 1989: 6). It is these culturally defined packages that we, and our students, need to transcend.

Without question, Nafsa, other international education associations and study abroad providers, should join with those organizations which are resisting defining education as a commodity that is a tradable service within the context of GATS. We should affirm that international education exists to serve the global public interest and that it must not be dealt with as a commodity, nor should students be considered consumers. It might also be useful to set standards regarding the "selling" of study abroad programs. In a somewhat light-hearted vein, we could perhaps also join together to provide annual "awards" to those organizations that have engaged in the kind of egregious advertising of study abroad programs that Mike Woolf has highlighted. A bit of derision might go a long way for those who suggest that "when you tire of techno, have a quiet drink with Taoist monks".

The above challenges of a structural and cultural nature also cry out for a more positive strategy with which to inform the programs we create for students. The decision to study abroad suggests that to a greater or lesser extent a student is open to experiencing realities that may allow them to situate their home reality as simply one among many - not intrinsically better, nor intrinsically worse, just different. As Clarke notes such an "expanded consciousness is found in the ability to take one's own private and/or sectional interests and measure them against other perspectives". In other words, "the responsibility of such individuals is that they make reflective judgements" (Clarke, 1996: 104). 
This perspective should be central to our work as international educators. Regardless of the type of program, we should be building in reflexivity - reflexivity about the culturally constructed nature of one's self, one's home society, and our understanding of the larger world. This requires that we in particular support a reflexive perspective about how the dominant economic and political structures in the world are constructed and institutionalized so that students recognize that war, injustice, and poverty are institutionalized in the global order. Only by engaging in dialogue with our students and asking, "Why? Does it have to be this way?», as Paulo Freire suggests (Freire, 1985: 113), will we prepare students for the extraordinary challenges they will have to face in the 21st century.

\section{A Cautionary Note}

Many of us who work in international education are trying to encourage a new mode of thinking - as I am implicitly suggesting above - that may lead to action that helps to create a more peaceful, just, and egalitarian global order. However, we must be wary of the tendency to be utopian.

Writing in the mid 1980's, Vaclav Havel noted that "the word "peace" has been drained of all content" (1990: 166). The problem was, and still is, that "peace", as with other utopian ideas, "ceases to express the transcendent dimension of being human and degenerates into a substitute for it" (Havel, 1990: 175). Thus, Havel argued, "the project for a better world, ceases to be an expression of man's responsible identity and begins, on the contrary, to expropriate his responsibility and identity" because "the abstraction ceases to belong to him and he instead begins to belong to it" (Havel, 1990: 175). Havel argued that the genesis of the problem with "peace" is rooted in the anomic individual's desire for mastery and control, in a manner that is not dissimilar in my opinion from that of the nuclear strategists I studied during that period: "They are the people tragically oppressed by the terror of nothingness and fear of their own being, who need to gain inner peace by imposing order ("peace") upon a restless world, placing in a sense their whole unstable existence into that order, ridding themselves of their obsessions once and for all" (Havel, 1990: 173). As with the nuclear strategists, their angst drives them "to construct and impose various projects directed toward a rationally ordered common good" and "their purpose is to make sure that, at long 
last, things will be clear and comprehensible, that the world will stride onward toward a goal, finally putting an end to all the infuriating contingency of history" (Havel, 1990: 173).

In terms of matters discussed in this essay, what Havel is warning against is an attempt to turn "peace and justice", or "global civil society", for example, into a meta-narrative. Rather than a unitary vision, what international educators may want to do is to help students reflect on the many manifestations of peace and justice, and to celebrate the infuriating contingency of history". In a similar way, a global civil society is likely to be an untidy phenomenon that resembles a work in progress, rather than a finished totality. This also implies that a different ethical perspective should inform our work.

The contemporary Irish philosopher Richard Kearney, has provided some proposals which might make the task more concrete without resorting to a grand meta-narrative of morality and ethics. In The Wake of Imagination (Kearney, 1988), Kearney argues that although deconstructive and other forms of post modern expression have helped to destroy the traditional bases for ethics, an ethical imagination can, and must, be based on the concrete others with whom we are confronted. The only possible response left, Kearney says, is to "the face of the other" (Kearney, 1988: 361). This is similar to Martha Nussbaum's insight that, "Citizens who cultivate their humanity need, further, an ability to see themselves [...] above all, as human beings bound to all other human beings by ties of recognition and concern" (Nussbaum, 1997: 10).

Kearney also notes that it is the face of the other which "resists assimilation to the dehumanising processes of commodity fetishism" (Kearney, 1988: 361). The dehumanising of others in "non-traditional" study abroad locations where the poor, for example, become commodities, is exactly what Mike Woolf is criticizing in his article, "Come and See the Poor People: The Pursuit of Exotica" (Woolf, 2006).

This is not to suggest that there cannot be a universal ethics, but as international educators we should know that the universal must proceed from the particular and not the other way around. In order that such an ethics should not "degenerate into censorious puritanism or nostalgic lamentation" however, Kearney also argues that ethics "must also give full expression to its poetical potential" (Kearney, 1988: 366). Historically, he claims, the ethical or poetical aspect of the imagination has been dominant, but instead of continuing this separation, he urges a synthesis of the two because the logic of the unconscious imagination "is one of both/and rather than either/or (Kearney, 1988: 368). It is therefore 
"inclusive and, by extension, tolerant; it allows opposites to stand, irreconcilables to co-exist, refusing to deny the claim of one for the sake of its contrary, to sacrifice the strange on the altar of self-identity" (Kearney, 1988: 368). Thus, Kearney wants us to understand poetry as "a creative letting go of the drive for possession, of the calculus of means and ends" (Kearney, 1988: 386). Taken together, the poetical and ethical imagination "signals a call to abandon the priority of egological existence", for "without the poetical openness to the pluri-dimensionality of meaning, the ethical imagination might well shrink back into a cheerless moralizing, an authoritarian and fearful censorship" (Kearney, 1988: 386).

Aren't these the perspectives that we hope our students will develop when they study abroad? In my opinion, these are precisely the sentiments necessary to have a viable cosmopolitan civil society at either the local or the global level, and it is this sensibility that should color our work in international education. One person who knew the importance of conjoining such a poetical and ethical imagination, was my friend the late Ron Moffatt, Nafsa's President in 2007. He wrote the following that year:

As international educators shaping our global future, we share a compelling responsibility and a unique power to envision possibilities commensurate with the challenges we face. We must act now to foster and connect learning communities that will create a more just, compassionate and sustainable world for all. We must prepare tomorrow's leaders to create a global civil society wherein perspectives are exchanged in pursuit of understanding, aspirations are transformed into deeds that enrich the human spirit, borders become invisible, nations become people, common ground is nurtured, partnerships flourish and goodwill prevails.

What I hope is that international educators will individually and through the organizations to which they belong like Nafsa, begin to insure that the educational programs they support truly address the serious systemic problems that we face as humans living on this planet. This cannot be done by simply going about our ordinary routines with our limited personal and national assumptions. International educators, more than other professionals, should see that they are part of a worldwide movement to create a viable, tolerant and open global civil society that will help to address those problems. Nafsa itself is one of the largest global civil society organizations on the planet, even though its members may for the most part be unconscious of this. The practice of study abroad itself as the 2002 Global Civil Society Yearbook pointed out, is a strong indicator of an emerging global civil society, and the express intent of most study abroad programs is to foster the sensibility - cross-cultural learning, immersion, etcetera, that is necessary to help create the kinds of "citizens" 
that a global civil society requires. Only through such a re-conceptualized and engaged citizenship can we hope that our children's children will live on a planet of the sort that Ron Moffatt envisaged.

\section{Bibliography}

AitKenhead, D. (2008): "Enjoy life while you can", The Guardian, March 1. American Council on Education (1995): Educating Americans for a World in Flux: Ten Ground Rules for Internationalizing Higher Education, Washington D.C., ACE.

Bellah, R., R. Madsen, W. Sullivan, M. A. Swidler, A. and S. Tipton, (2007):

Habits of the Heart: Individualism and Commitment in American Life, Berkeley, University of California Press.

- 1992): The Good Society, New York, Vintage.

Clarke, P. B. (1996): Deep Citizenship, London, Pluto Press.

Edwadrs, M. (2004): Civil Society, Cambridge, Polity Press.

Freire, P. (1985): The Politics of Education: Culture, Power, and Liberation, South Hadley, Mass, Bergin \& Garvey Press.

Friel, B. (1981): Translations, London, Faber \& Faber.

Fukuyama, F. (1993): The End of History and the Last Man, New York, Harper Perennial.

Glasius, M., M. Kaldor, and H. Anheir, (eds) (2002): Global Civil Society 2002, Oxford, England, Oxford University Press.

HARPer, C. (2008): Environment and Society, Upper Saddle River, NJ, Prentice Hall.

Havel, V. (1990): Living in Truth, London, Faber \& Faber.

Kaldor, M. (2003): Global Civil Society: An Answer to War, Cambridge, England, Polity Press.

Kearney, R. (1988): The Wake of Imagination, London, Hutchison.

Konrad, G. (1984): Antipolitics: An Essay, San Diego, Harcourt Brace Jovanovich.

Kovel, J. (1981): The Age of Desire, New York, Pantheon Books.

Lasch, C. (1984): The Minimal Self, New York, W. W. Norton \& Company. - (1979): The Culture of Narcissism, New York, W. W. Norton \& Company. Michnik, A. (1987): "The New Evolutionism", in Letters from Prison and Other Essays, Berkeley, University of California Press.

MoffatT, R. (2007): "The Path Ahead", WLM Plenary Speech, January 26.

Nussbaum, M. (1997): Cultivating Humanity: A Classical Defense of Reform in Liberal Education, Cambridge, Mass, Harvard University Press. 
Percy, W. (1989): The Message in the Bottle, New York, Farar, Straus, and Giroux.

Putman, R. (2001): Bowling Alone: The Collapse and Revival of American Community, New York, Simon \& Schuster.

ReEs, M. (2003): Our Final Century, London, Random House.

SAID, E. (1993): Culture and Imperialism, London, Chatto and Windus.

Woolf, M. (2006): "Come and See the Poor People: The Pursuit of Exotica", Frontiers: The Interdisciplinary Journal of Study Abroad, vol. XIII, November, pp.135-146.

Unesco, (2004): Higher Education in a Globalized Society, Paris, UnEsco. United Nations Commission on Human Security, (2003): Human Security Now, New York, United Nations Commission on Human Security. 